\title{
Exílio da ditadura na ficção brasileira da geração pós-memorial: a perspectiva e a estética dos filhos
}

\author{
Exile of the Dictatorship in Brazilian Fiction of the Post-Memorial Generation: \\ The Children's Perspective and Aesthetics \\ El exilio de la dictadura en la ficción brasileña de la generación posmemorial: \\ la perspectiva y la estética de los niños
}

Ilana Heineberg*

\begin{abstract}
Resumo
A partir do conceito de pós-memória, de Marianne Hirsch, este artigo pretende analisar a maneira pela qual artistas brasileiros, pertencentes à geração de filhos dos exilados políticos das ditaduras latinoamericanas, representaram suas vivências, suas memórias e as narrativas dos pais. Para tanto, selecionamos A chave de casa, de Tatiana Salem Levy (2007); Mar azul, de Paloma Vidal (2012); A resistência, de Julián Fuks (2015); Rio-Paris-Rio, de Luciana Hidalgo (2016); e o filme Deslembro, de Flávia Castro (2018). Num primeiro momento, serão abordadas as conexões entre intriga ficcional e memória familiar para, em seguida, analisar as estratégias narrativas de representação, muitas vezes indireta, dessa memória, buscando delinear o que seria uma estética pós-memorial brasileira. Finalmente, será tratada a representação do exílio, tanto como elemento transgeracional como cenário de uma perspectiva descentrada.
\end{abstract}

Palavras-chave: pós-memória, ditadura, América Latina, exílio.

\section{Abstract}

In this article I will explore Dominique Viart's Based on the concept of post-memory, by Marianne Hirsch, this paper aims to analyze the way Brazilian artists, belonging to the generation of children of political exiles from Latin American dictatorships, represented their experiences, their memories and their parents' narratives. To this end, we'll approach Tatiana Salem Levy's A chave de casa (2007), Paloma Vidal's Mar Azul (2012), A Resistência, by Julián Fuks, (2015), Rio-Paris-Rio (2016), de Luciana Hidalgo, and the film Deslembro (2018), by Flávia Castro. At first, we will approach the connections between fictional intrigue and family memory, and then analyze the narrative strategies of representation of this often indirect memory, seeking to delineate what would be a Brazilian post-memorial aesthetic. Finally, we will examine the representation of exile as both a transgenerational element and a scenario from a decentralized perspective.

Keywords: post-memory, dictatorship, Latin America, exile.

\section{Resumen}

Basado en el concepto de posmemoria, de Marianne Hirsch, este artículo tiene como objetivo analizar la forma en que los artistas brasileños, pertenecientes a la generación de hijos de exiliados políticos de las dictaduras latinoamericanas, representaron sus experiencias, sus recuerdos y las narrativas de sus padres. Con este fin, abordaremos A chave de casa (2007), de Tatiana Salem Levy, Mar Azul, de Paloma Vidal (2012), A resistência, de Julián Fuks, (2015), Rio-Paris-Rio (2016), de Luciana Hidalgo, y la película Deslembro (2018), de Flávia Castro. Al principio, abordaremos las conexiones entre la intriga ficticia y la memoria familiar y luego analizaremos las estrategias narrativas de representación de esta memoria a menudo indirecta, buscando delinear lo que sería una estética posmemorial brasileña. Finalmente, nos interesará la representación del exilio como elemento transgeneracional y escenario desde una perspectiva descentralizada.

Palabras-clave: posmemoria, dictaduras, América Latina, exilio.

\footnotetext{
* Université Bordeaux Montaigne, Pessac, França. Dorcid.org/0000-0002-4158-0115. E-mail: ilana.heineberg@u-bordeaux-montaigne.fr
} 
Deslembro incertamente. Meu passado

Não sei quem o viveu. Se eu mesmo fui,

Está confusamente deslembrado

E logo em mim enclausurado flui.

Fernando Pessoa

Geração pós-memorial é o termo usado pela comparatista Marianne Hirsch a partir dos anos 1990 para referir-se à produção artística de filhos ou netos de vítimas de traumas e sobreviventes de catástrofes humanitárias. Em sua formulação inicial, sobretudo em Family frames (Hirsch, 1997), a definição de pós-memória estava ligada especificamente à Shoah e à transmissão inter e transgeracional. ${ }^{1}$ Marianne Hirsch é filha de judeus romenos que sobreviveram à Segunda Guerra Mundial e se exilaram nos Estados Unidos quando ela tinha 13 anos, em 1962 (Hirsch, 2014, p. 330-331). O termo surge, portanto, da sua própria biografia (Hirsch, 2012, p. 4), especialmente da sua relação com as histórias contadas pelos seus pais. Hoje, o termo expandiu-se referindo-se a inúmeros acontecimentos violentos e traumáticos da história mundial. Na definição de Marianne Hirsch:

O termo pós-memória descreve a relação que a "geração seguinte" mantém com o trauma cultural, coletivo e pessoal vivido por aqueles que a precederam. Ele diz respeito, portanto, a experiências das quais essa geração só pode "lembrar" através das histórias, imagens e comportamentos em meio aos quais ela cresceu. Mas essas experiências lhe foram transmitidas de maneira tão profunda e afetiva que parecem constituir sua própria memória. A relação da pós-memória com o passado é, na realidade, assegurada pela mediação e não por lembranças, mas projeções, criações e investimentos imaginativos (Hirsch, 2014, p. 205, tradução nossa).

No âmbito latino-americano, o termo aparece primeiramente nos estudos sobre a Shoah para referir-se aos filhos de sobreviventes do nazismo e, a seguir, aplicado à situação dos filhos de desaparecidos políticos nas ditaduras latino-americanas (Szurmuk e Irwin, 2009, p. 226). A crítica cultural Beatriz Sarlo desaprova o uso incorporando-o à sua crítica da virada subjetiva na pesquisa acadêmica (Szurmuk e Irwin, 2009, p. 227).

Propomos refletir aqui sobre a maneira como a geração de artistas brasileiros da pósmemória representou o exílio provocado pelas ditaduras latino-americanas, e particularmente a brasileira, na narrativa literária e no cinema recentes. Para tanto, convocamos A chave de casa de Tatiana Salem Levy (2007), Mar azul de Paloma Vidal (2012), A resistência, de Julián Fuks (2015), Rio-Paris-Rio de Luciana Hidalgo (2016) e o filme Deslembro de Flávia Castro (2018).

Essas obras representam o exílio como uma experiência traumática e são marcadas por estratégias narrativas e de representação tipicamente pós-memoriais. Os autores pertencem à geração que não viveu diretamente os traumas da ditadura, mas o fez de maneira indireta através das migrações forçadas que eles mesmos viveram quando crianças e das narrativas transmitidas de maneira afetiva e profunda pelos pais ou pela geração anterior a de seus pais. A maioria das obras se caracteriza pela porosidade entre criação ficcional e memória autoral, sendo em maior ou menor medida uma escrita de si que inclui uma reflexão metaficcional sobre essa modalidade de escrita ou de representação. $O$ fato de misturarem elementos autobiográficos e ficção corresponde justamente ao "investimento imaginativo" que menciona Marianne Hirsch na citação acima. A única exceção nesse sentido é Rio-Paris-Rio, que não parte da memória familiar, tornando-se emblemático de uma noção mais abrangente da geração da pós-memória, abrindo-a não somente a outros eventos traumáticos além da Shoah, mas a toda

\footnotetext{
${ }^{1}$ Em The generation of postmemory: writing and visual cultural after the Holocaust, cujo título já sublinha o uso mais abrangente do termo, Marianne Hirsch explica que, a partir da segunda década do século XXI, sua análise dialoga com inúmeros contextos diferentes de transmissões traumáticas como: a escravidão africana no continente americano, a guerra do Vietnã, o Apartheid na África do Sul, o genocídio em Ruanda e as ditaduras latino-americanas, que nos interessam mais de perto aqui, entre outras (Hirsch, 2012, p. 18-19). Através dessa abertura, Marianne Hirsch destaca a importância da noção de conexão de sua abordagem da pósmemória, tanto pela constatação de uma estrutura estética transnacional (Hirsch, 2012, p. 24) quanto pela marca das novas tecnologias mediáticas deixadas na representação da pós-memória.
} 
uma geração, inclusive àqueles que não são literalmente filhos das vítimas. Segundo Marianne Hirsch, a pós-memória, além de vertical e intergeracional, também pode se dar por afiliação ou familiaridade, fazendo com que a posição de filho seja passível de assimilação a toda uma geração capaz de se identificar com ela, sendo, por tudo isso, também uma transmissão horizontal e intrageracional (Hirsch, 2012, p. 36). No Brasil, Eurídice Figueiredo tocou em muitas dessas questões em A literatura como arquivo da ditadura brasileira (2017), sobretudo no capítulo "Os filhos do exílio", embora não tenha empregado o termo pós-memória.

Num primeiro momento, abordaremos as conexões entre intriga ficcional e memória familiar. A seguir, analisaremos estratégias narrativas de representação dessa memória "de segunda mão" (Bayard, 2013, s.p.) buscando delinear uma estética pós-memorial de artistas brasileiros. Finalmente, focalizaremos a representação do exílio.

\section{Pós-ficções da geração pós-memorial}

Narrado em terceira pessoa, Rio-Paris-Rio focaliza-se no exílio da brasileira Maria, em Paris, onde ela estuda filosofia e apaixona-se por Arthur, com quem participa do movimento de maio de 1968. Como vimos, consideramos aqui o romance de Luciana Hidalgo como emblemático de uma noção mais abrangente da geração pós-memorial, abrindo-a não somente a outros eventos traumáticos além da Shoah, mas a toda uma geração inclusive àqueles que não são literalmente filhos das vítimas. De fato, a história familiar de Luciana Hidalgo não tem ligação com o exílio ou a ditadura. Segundo conta (Hidalgo, 2017, s.p.), ela nasceu com a ditadura militar já instaurada e foi uma "criança politicamente alienada": "só despertei para o horror do autoritarismo ao ler, já na adolescência, O que é isso, companheiro?, de Fernando Gabeira". Ou seja, a literatura memorialística da ditadura funcionou como estrutura de mediação para autora, que integra, a partir da publicação do seu romance, o que Marianne Hirsch chama de "rede de transmissão pós-memorial" (Hirsch, 2012, p. 36). Assim, podemos nos perguntar de que modo os "afiliados" da geração pós-memorial representam o exílio e como se diferenciam da geração pós-memorial dos filhos.

As outras obras que reunimos aqui são de autores cujos pais tiveram de exilar-se por estarem envolvidos em movimentos clandestinos de combate às ditaduras latino-americanas, embora este não constitua necessariamente o tema central das intrigas. É o caso de Paloma Vidal, filha de psicanalistas argentinos. Em Mar azul, a narradora septuagenária lê os diários do seu pai, que a deixara ainda criança com a vizinha quando fora morar no Brasil, buscando neles qualquer sinal de afeto ou preocupação em relação a ela ao mesmo tempo que escreve seu próprio diário - o livro que lemos - em função das rememorações e de seu cotidiano. Paloma Vidal divide com sua narradora a nacionalidade argentina, a instalação na cidade do Rio de Janeiro, o bilinguismo, a profissão de professora universitária na área de Letras. A autora é filha de exilados do regime instaurado em 1976 na Argentina, enquanto sua heroína, jovem, exila-se depois do desaparecimento político de Vicky, sua melhor amiga, ao lado de quem cresceu depois da partida do seu pai. Em seu livro, a filha do exílio retoma, por meio da sua personagem, a situação de seus pais. Essa interferência entre real e ficção em Mar azul passa pelo mimetismo de uma forma de escrita íntima, o diário. A narradora, anônima, confirma o gênero por sua negação: "Isto não é um diário, nem uma carta, nem uma autobiografia, nem qualquer outro modo de escrita íntima" (Vidal, 2012, loc. 594).

Do mesmo modo, Flávia Castro, que escreveu e dirigiu Deslembro (2018), tem muitos pontos em comum com Joana, a heroína do filme. Ela também conheceu o exílio na França, também relutou e sofreu ao retornar ao Brasil em 1979, onde viveu seu segundo exílio, separando-se dos amigos e de uma cultura da qual ela havia se apropriado. Contrariamente à Joana, cujo pai foi desaparecido antes do exílio, sendo o acesso a essa memória o tema central do filme, Flávia Castro perdeu seu pai somente nos anos 1980, em circunstâncias misteriosas que constituem a trama do seu documentário Diário de uma busca (2010).

Já $A$ chave de casa, primeiro romance de Tatiana Salem Levy, reivindica-se como uma autoficção e comporta fragmentos sobre a militância, a clandestinidade, a prisão da mãe e o exílio dos seus pais em Portugal durante a ditadura brasileira. O romance trata sobretudo da 
busca identitária da narradora através de duas viagens. A primeira à Turquia, em busca do passado da família sefaradita do seu avô materno. A segunda a Portugal, país natal da autoranarradora, deixado quando esta tinha 9 meses, no momento da anistia de 1979. A escrita e os deslocamentos permitem à narradora sair de seu estado de paralisia (que o leitor jamais saberá se física, imaginária ou metafórica) e a elaborar a perda da sua mãe e uma ruptura amorosa ambivalente com um homem violento. Se a ditadura não está no centro da intriga de $A$ chave de casa, ela volta a aparecer nos romances seguintes de Tatiana Salem Levy, demonstrando que a herança dessa memória permeia sua obra. ${ }^{2}$ A narradora de $A$ chave de casa não é nomeada, mas sua identidade coincide com a identidade civil de Tatiana Salem Levy: filha de exilados da ditadura brasileira em Portugal, detentora de um passaporte português e neta de imigrantes judeus da Turquia. Segundo Luciana Hidalgo (2013, p. 220), Tatiana Salem Levy é a segunda romancista, depois de Silviano Santiago com seu livro de contos Histórias mal contadas (2005), a reivindicar a etiqueta da autoficção, a partir de seu contato com essa tendência na França durante uma temporada de pesquisa em Paris para o seu doutorado, que consistia na própria escrita de $A$ chave de casa, seguido de um ensaio teórico.

Julián Fuks, autor de A resistência (2015), é, como Paloma Vidal, filho de psicanalistas argentinos exilados. E, como Tatiana Salem Levy, ele assume a ficcionalização da sua vida. Para além da história do irmão adotado durante a ditadura, da militância e do exílio dos pais, o romance busca dar conta - como o próprio título indica - das possibilidades e impossibilidades da ficção de dizer o que escapa às palavras e à narrativa, na continuidade de um trabalho metaficcional iniciado em seu primeiro romance Procura do romance (2011). Julián Fuks recebeu os prestigiosos prêmios Jabuti (2016) e José Saramago (2017) por A resistência. O narrador e autor do romance são muito semelhantes, mas não se fundem em uma só personagem. O narrador e alter ego de Julián Fuks também tem um nome castelhano que termina com a mesma sílaba, fazendo eco ao nome do narrador. É apenas no final do romance, que o pai se dirige a ele chamando-o pelo nome de nascimento, "Sebastián", para lhe dar o seu aval para a publicação: "Vá em frente, Sebastián" (Fuks, 2015, p. 137). No início do romance, o leitor já compreendera que se trata do mesmo narrador de Procura do romance: "Escrevi um livro inteiro a respeito da experiência de caminhar pelas ruas de Buenos Aires e observar o rosto das pessoas" (Fuks, 2015, p. 18). Com esse gesto, Julián Fuks retoma ao mesmo tempo que transforma o gesto proustiano de escrita de si em vários volumes.

Podemos então propor uma gradação nos romances do nosso corpus, indo do puramente ficcional Rio-Paris-Rio, passando pela categoria intermediária da obra inspirada em fatos autobiográficos, como Mar azul e Deslembro, a obras próximas da autofiç̧ão, como A chave de casa e $A$ resistência. As duas últimas narrativas, jogam com a "dupla recepção, ao mesmo tempo ficcional e autobiográfica" (Gasparini, 2014, p. 14, tradução nossa), que caracteriza a categoria autonarração na qual Philippe Gasparini classifica tanto o romance autobiográfico quanto a autoficção. Se Tatiana Salem Levy, como vimos, classifica seu romance dentro da categoria autoficção, para Julián Fuks, a definição de gênero não pode se dar no momento da recepção, pois sua narrativa só ganha sentido quando uma parte da sua própria experiência é levada em consideração. ${ }^{3}$ Embora chame atenção para o caráter autobiográfico de A resistência, o escritor prefere o termo "pós-ficção", que ele define da seguinte forma:

É uma tentativa de ampliar e transformar a ideia de autoficção. A definição de autoficção é centrada na figura do autor, que ficcionaliza suas vivências, aproximando o romance da autobiografia. Mas uma questão mais ampla é o modo como a literatura tem tocado diretamente diversas realidades e se deixado atravessar por diversos discursos, além do autobiográfico, como os discursos histórico, político e ensaístico. O termo "autoficção" não dá conta da literatura atravessada por todos esses processos, pois fala só da ficção

\footnotetext{
${ }^{2}$ Em Dois rios (2012), o avô paterno da narradora e do narrador - irmãos gêmeos - era militar e trabalhava no presídio de Dois Rios, em Ilha Grande, que recebeu presos políticos e, em Paraíso (2016), os pais da heroína Ana militaram clandestinamente no PCdoB.

${ }^{3}$ Durante o debate "Autoficção ou Pós-Fiç̧ão: a fadiga do eu", que ocorreu no dia 26 de setembro de 2018 no SESC Paulista, Julián Fuks afirma: "Não cabe ao autor instruir como ler o livro, só que a configuração da matéria narrada é completamente diferente quando você tem a história. Eu nunca escreveria um livro como A resistência se eu não tivesse um irmão adotivo. A pertinência desse narrar vem dessa vivência" (Marchetto, 2018). Consultar também Fuks (2017).
} 
atravessada pela biografia. O que me interessa é a ficção que se deixa permear pelo real, se confunde com o real, se funde com o real. A "pós-ficção" é uma ficção transformada, ocupada pelo real (Fuks, 2017b, s.p.).

Se o "pós" de "pós-ficção" situa o romance de Julián Fuks em uma zona cinza entre real e ficção, ele também permite apreender a estrutura da pós-memória. Como sublinha Marianne Hirsch, "estamos na era dos "pós'” (Hirsch, 2012, p. 5) - pós-colonial, pós-memória, póshumano, pós-moderno etc. -, e o prefixo não indica uma posição temporal, um "após", mas antes "uma continuidade incômoda" (Hirsch, 2012, p. 5), com o termo principal, "instaurando ao mesmo tempo uma distância crítica e uma interação" (Hirsch, 2012, p. 5), enfim, uma "oscilação entre continuidade e ruptura" (Hirsch, 2012, p. 6). As narrativas do nosso corpus - o caso mais emblemático é o de A resistência - constroem-se tanto como ficções impregnadas de real como memórias impregnadas de imaginação, o que se traduz em uma porosidade entre o texto e seus referentes. Dessa maneira, podemos considerar que pós-memória e pós-ficção são duas perspectivas complementares para descrever a categoria de produção artística com inúmeras características comuns que nos propomos a analisar aqui. Se a pós-memória se focaliza na expressão artística da mediação da memória pelas gerações subsequentes ao trauma, a pós-ficção, por sua vez, acentua a ambivalência entre o real e a ficção. ${ }^{4}$

Nas obras analisadas aqui, a permeabilidade entre a ficção e o real também remete aos binômios intriga/história ou memória/história. Quando o narrador de $A$ resistência afirma a respeito da sua escrita que "Isto não é uma história. Isto é história" (Fuks, 2015, p. 23), ele está, ao nosso ver, indicando a maneira pela qual a memória individual e a memória social se entrelaçam, bem como a interferência da projeção da memória social na memória individual e vice-versa. Marianne Hirsch sustenta que o trabalho pós-memorial permite justamente "reativar" e "reencarnar" (re-embody) uma memória cujos arquivos perderam os elos com o passado, como é o caso de situações de trauma, catástrofe e exílio (Hirsch, 2012, p. 33-34). Assim, a afirmação do narrador de Julián Fuks colocando-nos "na história" permite-nos apreender a reflexividade do romance muito além do narcisismo, mas como uma característica de um gênero que aborda a escrita da história pelo viés da memória. Isabelle Grell considera a autoficção como "um gênero engajado" ou, mais precisamente, citando Claude Burgelin, como um gênero "nascido da História; da necessidade que sentiram tantos escritores (muitas vezes eles próprios vindos de outros lugares, de uma terra ou de uma língua perdida) de darem contorno, sentido, limites e, por vezes, sepultura às histórias dos seus" (Burgelin apud Grell, p. 63, tradução nossa).

Em Rio-Paris-Rio a demanda de real se efetiva pela preocupação com uma ancoragem histórica, que inclusive levou a autora a se deslocar para escrever parte do romance em Paris. A ditadura brasileira ganha mais espaço na narrativa à medida que Maria vive e observa a repressão policial de Maio de 1968. A protagonista não se deixa levar pelo movimento da multidão, tanto em relação ao regime brasileiro, quanto à situação dos estudantes franceses, ela assume uma posição descentrada: "Faz um esforço para acompanhar os amigos em seus excessos, cada vez mais exaltados, desafiando a polícia num país que não lhes pertence, penetras nessa grande festa que é Paris. Clandestinos, deveriam se comportar como tal, discretos, invisíveis. Ao contrário, avançam" (Hidalgo, 2016, loc. 932). É interessante notar que a publicação do romance situa-se próxima ao cinquentenário da revolta dos estudantes, que rendeu inúmeras publicações na França, ${ }^{5}$ contribuindo com uma visão transnacional das revoltas sociais da virada para os anos 1970.

\footnotetext{
${ }^{4}$ Esses pontos em comum nos parecem tanto mais evidentes que nos seus ensaios respectivos Julián Fuks e Marianne Hirsch se debruçam na obra de W. G. Sebald mostrando-o como exemplo para seus conceitos. Marianne Hirsch (2012, p. 40-48) e Julián Fuks (2017, loc. 798-896) analisam o romance Austerlitz, respectivamente sob a perspectiva pós-memorial e pós-ficcional.

${ }^{5}$ Entre dezenas de livros lançados entre 2017 e 2018 que se voltam para os eventos de Maio de 1968, podemos destacar os olhares historiográficos de Ludivine Bantigny e de Eric Alary, respectivamente em De grands soirs en petits matins e Il y a 50 ans! Mai 68 ; as perspectivas filosóficas de Alain Badiou (2018) e de Michel Onfray (2018), sem esquecer a elaboração ficcional de Pauline Dreyfus (2017) em que "pequena" e "grande" história se justapõem assim como real e fíç̧ão.
} 
Ao se alimentarem da história e sobretudo da memória, mas também preenchendo as lacunas, essas ficções tornam-se voluntariamente híbridas. Veremos a seguir de que formas, além de insumo para narrativa, a memória também se vê representada nesta última.

\section{Pós-memória, rastros do passado e mise en abyme - Geração 1.5}

Contar o passado traumático significa conclamar a memória. A fragmentação e a não linearidade das narrativas da geração pós-memorial traduzem os caminhos percorridos pela memória das personagens, ativadas ora por objetos de família - sobretudo as fotografias - ora por simples rememoração de conversas e de narrativas em primeira pessoa dos pais. Julián Fuks e seu personagem Sebastián; Flávia Castro e Joana; Tatiana Salem Levy e sua narradora anônima; e Paloma Vidal (mas não a sua heroína) pertencem à geração 1.5. Por analogia à definição de Susan Rubin Suleiman sobre os jovens sobreviventes da Shoah, consideraremos que autores, narradores e personagens em questão são "jovens demais para ter uma compreensão adulta sobre o que aconteceu, mas suficientemente grandes para terem estado lá" (Suleiman, 2002, p. 277). Essa noção de uma geração intermediária torna-se mais precisa quando as obras evocam a dificuldade de se lembrar da infância.

Tatiana Salem Levy dedica sete capítulos de $A$ chave de casa à militância política dos pais durante a ditadura: dois que os mostram vivendo na clandestinidade, alojados "num quarto-esala na periferia da cidade, um apartamento arranjado pelo próprio partido" (Levy, 2007, p. 126); três dedicados às torturas sofridas por sua mãe na prisão; o reencontro dos pais quando a mãe sai da prisão; a despedida da mãe e avó no consulado da Costa Rica antes da partida para o exílio em Portugal; o retorno ao Brasil depois da anistia de 1979. A perspectiva narrativa adotada nesses capítulos comporta um distanciamento narrativo. A narradora desaparece completamente da ação: ela não mostra sua ligação com as personagens e emprega a terceira pessoa. No último capítulo desta sequência dispersa no romance, ela própria se apresenta na terceira pessoa: "o bebê" (Levy, 2007, p. 188), "a filha" (Levy, 2007, p. 190). Através dessa técnica, Tatiana Salem Levy representa a constituição da memória da autora-narradora a partir da narrativa dos adultos presentes no aeroporto naquele dia. O mesmo ocorre quando a narradora recorre a uma história familiar que atravessou gerações ganhando praticamente o estatuto de conto de fadas: "Quando eu era pequena, minha mãe me narrou uma história que seu pai havia lhe contado quando ela também era pequena. De quando em quando, percebo-me saindo do presente e retornado a essa mesma história, como se de alguma forma ela fosse minha, tamanho o pavor que desperta" (Levy, 2007, p. 75).

Sebastián, por sua vez, não deixa de usar a primeira pessoa, embora se mostre consciente de escrever a partir de outras narrativas e não de fatos: "este meu relato vem sendo construído há tempo pelos meus pais, que pouco me desvencilho de sua versão dos fatos. Ao vê-los, sinto que sou em parte um ser que eles moldaram para contá-los, que minha memória é feita de sua memória, e minha história haverá sempre de conter a sua história" (Fuks, 2015, p. 104).

O filme de Flávia Castro apresenta uma reflexão profunda sobre a memória e o esquecimento da geração 1.5. A heroína tinha cerca 3 anos quando o pai "desapareceu" e ela e a mãe tiveram de se exilar em Paris. Na primeira metade do filme, Joana obstina-se com os sentidos da palavra "desaparecido". À mãe, questiona a incongruência dessa palavra para designar um morto, questionando se o pai é um desses "caras que vão comprar cigarro na esquina e não voltam nunca mais" (Deslembro, 2018, 33m03s). À avó, mais tarde, pergunta com doçura infantil se a palavra não poderia significar a esperança de uma volta (Deslembro, 2018, $57 \mathrm{~m} 50 \mathrm{~s}$ ) ao que a avó responde por um longo silêncio, mais doloroso do que incômodo. Vários diálogos mostram que as palavras têm importância para Joana, leitora voraz dos clássicos franceses, em situação de bilinguismo ou trilinguismo (se contarmos o espanhol do padrasto e sua família), portanto habituada ao ato de traduzir, pesar as diferenças e fazer pontes. Desse modo, o sentido da palavra "desaparecer" passa a remeter também às suas lembranças.

Contrariamente a Sebastián, que reconstitui a sua infância a partir da narrativa dos pais, parte da memória de Joana encontra-se "impedida" (Ricœur, 2000, p. 575-580) pelo trauma e pelo 
silêncio dos adultos que não querem mais lembrar, mas também pelo clima de esquecimento gerado pela Lei de Anistia. ${ }^{6}$ O próprio título do filme, ao empregar essa palavra pouco usual na língua portuguesa, dá a entender que o "deslembro" de Joana - que no título também pode ser compreendido como o verbo conjugado na primeira pessoa - é uma necessidade de sobrevivência e, ao mesmo tempo, algo que, embora de maneira inconsciente, já é sabido. O prefixo "des" associado ao verbo lembrar tem mais um sentido de reversão do que de negação (Bona e Ribeiro, 2018), provocando um movimento contraditório. O valor de oxímoro do título Deslembro fica ainda mais claro quando Ernesto, que se exilou com seus pais em Portugal, declama a Joana o poema de Fernando Pessoa (parte dele citada na epígrafe deste texto) que começa justamente com essa mesma palavra. O percurso iniciático de Joana passa pela vontade de lembrar, insuflada pela convivência com a avó paterna no Rio de Janeiro. Toda a estética do filme está a serviço da representação do processo que permite a Joana ter acesso à sua memória, e junto com ela o espectador. Paralelamente, se dá a compreensão da dimensão traumática de sua experiência, acompanhada de culpa, que produziu o deslembro. Merecem menção especial a imagem e o som das gotas de chuva, as músicas brasileiras da infância e do início da década de 1980 e as imagens de rachaduras e falhas que servem de metáfora à memória 1.5 de Joana.

\section{Objetos}

Se a memória é por definição falha, diversos objetos são convocados nas obras analisadas para testemunhar ou acessar a história e a memória familiar. Se, como afirma Ricœur (2000, p. 511), a memória é a "representação presente do passado ausente", esses objetos são indícios do passado ou, na formulação de Marianne Hirsch, "telas para a memória" (screen memories) (Hirsch, 2012, p. 42). Em A resistência, pedaços de papéis em gavetas, listas de nomes, cartas, fotografias e recortes de jornais constituem rastros importantes do passado. Em Mar azul, a narradora escreve o próprio livro que estamos lendo, seu diário, no verso dos cadernos que serviram de suporte ao diário do seu pai, recebidos de herança. Desse modo, o ato de leitura dos cadernos do pai - em busca de qualquer referência afetiva à sua pessoa - e de escrita do seu cotidiano e das suas próprias memórias confundem-se num mesmo objeto que se apresenta na forma de um palimpsesto: "Escrevo no verso de suas folhas. Minha tinta se confunde com a dele" (Vidal, 2012, loc. 556). Em A chave de casa, a herança do objeto que desencadeia a viagem e o ato de escrita está presente no próprio título. Embora a narradora descubra rapidamente que a casa do avô em Esmirna já não existe, a chave que está em suas mãos abre as portas de uma memória transgeracional, mas também de Portugal e da Turquia para esta personagem que, até então, encontrava-se "paralisada", dando acesso ao deslocamento e à transmissão transgeracional, já que, na ausência da mãe, é a narradora que recebe a chave do avô.

As fotografias, apesar de sua materialidade, são particularmente passíveis de ficcionalização. Segundo Marianne Hirsch, elas "nos permitem, no presente, não apenas ver e tocar o passado, mas também reanimá-lo" (Hirsch, 2012, p. 36, tradução nossa) e, desse modo, "diminuir as distâncias, unir aquilo que está separado e facilitar a identificação e a afiliação" (Hirsch, 2012, p. 38). Essa capacidade de afiliação das fotos de família - pois Hirsch defende que as representações da família funcionam como uma língua franca da identificação - contribui para abrir a produção artística pós-memorial a toda geração seguinte, e não apenas aos filhos das vítimas. Além disso, Hirsch, a partir da leitura de Paul Connerton, considera a fotografia como uma "prática memorial inscritiva" (inscriptive memory), ou seja, que pode dar lugar à incorporação de certos aspectos do passado e estabelecer uma comunicação com a memória corporal do espectador (Hirsch, 2012, p. 38-39). Desse modo, quando Hirsch chama atenção para os "perigos da pós-memória", ela aproxima-se dos narradores que se questionam sobre a pertinência da sua memória e o medo de ficcionalizar os fatos.

\footnotetext{
${ }^{6}$ A partir da leitura de Paul Ricœur, Jacques Derrida e Michel de Certeau sobre a memória e o esquecimento, Jeanne Marie Gagnebin (2010) analisa a relação entre os esquecimentos ligados à ditadura - e válidos para outros eventos da história brasileira, como a escravidão e revoltas populares - e a normalização da exclusão no presente. Sobre a relação entre a Lei de Anistia brasileira e amnésia ver também: Figueiredo (2017), Finazzi-Agrò (2014), Lísias (2010), Seligmann-Silva (2014), Vecchi (2014) e Vidal (2003; 2015).
} 
As fotografias exercem um papel fundamental na economia narrativa de A resistência, permitindo ao narrador acessar diretamente as imagens que constituem sua memória. A passagem que menciona a imagem da preparação do álbum dentro do álbum revela o al to grau de autoconsciência da geração pós-memorial:

No álbum de fotos, há uma foto da minha mãe ordenando o álbum de fotos. Curioso registro de uma memória a se montar, de uma existência longínqua a se converter em narrativa numa sequência artificiosa de imagens; curiosa noção de que haveria algo de memorável na própria constituição da memória (Fuks, 2015, p. 104).

Essa mise en abyme, além de reforçar a importância das imagens para narrativa, acentua, mais uma vez, o processo de construção da pós-memória e inclusive chama atenção para a superposição e para a herança das construções feitas por cada geração.

Em Deslembro, a avó paterna transmite a Joana fotos, livros e recortes de jornais ligados ao desaparecimento do filho, mas também a sua narrativa sobre o desaparecimento deste, que, embora repleta de lacunas, permitirá a Joana construir a sua. As primeiras rememorações da heroína são breves, quase imagens sem movimento, com poucos objetos, sempre sem o rosto do pai, filmada em câmera subjetiva e na altura das pernas dos adultos. Ao reconhecer a sua boneca de pano Lili num dos recortes de jornal da avó é que as sequências de lembranças recalcadas aparecem ao leitor, ligando o desaparecimento do pai à presença da menina no "aparelho", portanto, à culpa desta última por acreditar que teria denunciado o pai ao recusar-se a usar o seu codinome.

Se Marianne Hirsch considera a fotografia principalmente como uma tela para as projeções da geração pós-memorial, Deslembro associa fotografias e outros objetos testemunhais ao resgate da memória infantil que a torna capaz de formular, senão uma narrativa, pelo menos perguntas precisas. Assim, a contemplação por Joana da única fotografia que a avó guardou do filho adulto - as outras haviam sido destruídas por medidas de segurança - se dá de forma ritualizada. Joana a recebe num envelope que, em vez de abrir, guarda imediatamente. Ela aguarda um momento de solidão para ver a imagem do pai, senta-se no chão, na rua, mais precisamente numa paisagem recorrente no filme - que o espectador não sabe exatamente onde se situa. Nesta vê-se os fundos de um prédio, provavelmente o de Joana, - áreas de serviço, pequenas janelas de quartos ou banheiros de empregada -, um estacionamento e uma enorme pedra de morro típica da paisagem do Rio de Janeiro contendo uma linha de fratura que atrai a câmera a cada passagem desta. Nesta cena, o enquadramento preserva a distância e o luto da heroína: Joana observa a foto sozinha e o espectador não tem acesso direto à imagem do pai, apenas vê os olhos da fotografia que parecem olhar Joana pela transparência do papel à luz do dia. A cena que mostra uma imagem mediada, espécie de palimpsesto, funciona como representação da pós-memória, superpondo passado e presente, o desaparecido e a deslembrada, o pai e a filha.

\section{Exílios transgeracionais e decentramentos identitários}

Além da representação de uma memória intermediada, as obras em questão abordam reflexões sobre a memória e a pós-memória do exílio.

\section{Exílios transgeracionais}

Para além dos exílios derivados da militância política, as migrações internacionais também marcam autores, narradores, seus pais e avós. Nos três romances de autoria de filhos de exilados políticos, a geração anterior também conheceu o exílio. Em Mar azul, o pai da narradora deixa a Argentina sem explicação e compreende-se que ele frequentava um grupo clandestino. Vale lembrar que o tema da mobilidade é um componente onipresente na obra de Paloma Vidal, a autora ficcionaliza sua própria experiência em Los Angeles no romance Algum lugar (2009), ao passo que a heroína de Mar azul parece imobilizada em sua cidade de 
adoção. Já em Ensaio de voo (2017), a própria situação de escrita desse texto híbrido - memória ou ensaio? -, no bloco de notas do celular, ocorre durante um voo transatlântico.

Nos romances de Tatiana Salem Levy e Julián Fuks, os narradores viajam à terra dos seus respectivos antepassados em busca de elementos para escrever a história que lemos. A narradora de $A$ chave de casa vive a experiência de encontrar a família e uma cultura que descreve de maneira exótica, apesar de sua ascendência e de sua "cara de turca": "Não, não sou brasileira, sou turca. Meus avós vieram daqui, são todos turcos. Eu também. Veja, não pareço turca? Olhe o meu nariz comprido, a minha boca pequena, os meus olhos de azeitona. Sou turca" (Levy, 2007, p. 46). Já seu passaporte português - obtido por ter nascido durante o exílio dos pais - destoa do sotaque brasileiro. O exílio é apresentado enfim como fio condutor da sua história familiar:

Nasci no exílio: em Portugal, de onde séculos antes a minha família havia sido expulsa por ser judia. Em Portugal, que acolheu meus pais, expulsos do Brasil por serem comunistas. Demos a volta, fechamos o ciclo: de Portugal para a Turquia, da Turquia para o Brasil, do Brasil novamente para Portugal. Não teria sido menos penoso, menos amargo, se não tivéssemos sido obrigados a fazer esse longo percurso? Por que tivemos de sair de um lugar para voltar ao mesmo lugar? (Levy, 2007, p. 25).

Sebastián, além da viagem a Buenos Aires para coletar material para o seu romance, considera importante mencionar a história de "deslocamentos incessantes" (Fuks, 2015, p. 34) dos seus antepassados. Do lado paterno, descende de uma família judia alemã que foge para a Argentina antes da Segunda Guerra Mundial. Do lado materno, as origens, menos precisas, remontam à Itália ou à Espanha, depois ao Peru até chegar ao Pampa argentino. O narrador pergunta-se: "Se muitos antes deles pareciam migrantes inveterados, se muitos haviam feito de suas casas meros contornos na paisagem afastada, arriscando esquecer os velhos rostos queridos, os esconderijos de infância, por que eles haviam resistido tanto a deixar o país que os amedrontava, e por que seria diferente a dor que sentiam agora?" (Fuks, 2015, p. 34). Ao perguntar-se sobre a particularidade do exílio político dos seus pais em relação a uma história familiar tão marcada por deslocamentos e fugas, Sebastián chama atenção para situações de bilinguismo, cultura e pertença duplas, bem como a busca de um passado perdido, presente tanto nos romances quanto nas vidas de Julián Fuks, Paloma Vidal e Tatiana Salem Levy. Nos três romances em questão, o exílio constitui ao mesmo tempo a riqueza e a dor das personagens, mesmo após várias gerações.

\section{Exílio e descentramento}

Em Rio-Paris-Rio, a perspectiva descentrada da ditadura brasileira também transfere o foco para questões de adaptação cultural, linguística, encontros entre jovens fugidos de diversos regimes autoritários: o espanhol Pablo, o português José, os brasileiros Marechal e Ciaiei. A heroína do romance não tentou combater o regime latino-americano, como os pais dos narradores que se exilaram em A chave de casa, Mar azul e A resistência e a heroína de Deslembro. Maria não é o que se pode chamar de uma personagem engajada: sua situação é mais ambígua. A estudante brasileira é neta de um general que participou do golpe de 1964. Os sentimentos de afeto, repúdio e vergonha em relação ao avô vão se delineando ao longo do romance como a principal causa do exílio em Paris, uma alternativa para fugir dos conflitos, estimulada pelo próprio pai, que não ousa um confronto aberto com o pai general. Nesse sentido, a miopia da personagem pode ser entendida como uma característica bastante significativa. O narrador menciona mais de uma vez a virada que representa na vida da personagem o diagnóstico do defeito de convergência quando criança, separando a infância sem óculos, em que o seu horizonte era visto como algo difuso e embaçado, e a fase com óculos, em que as coisas ganham um contorno preciso, a linha do horizonte torna-se "firme, bem traçada" (Hidalgo, 2016, loc. 1.720). Afastar-se do Brasil é, para Maria, voltar a ver de forma embaçada o seu próprio país, não encarar as idiossincrasias da sua posição no Brasil, da qual o leitor não saberá quase nada. Instalar-se em Paris é estabelecer uma distância que lente alguma poderá superar. Inversamente, ao ler Descartes, seu filósofo preferido, Maria aplica-se no gesto de endireitar os 
óculos da mesma forma com que observa a vida parisiense nos seus mínimos detalhes. São os eventos de Maio de 1968 que colocam em desordem as distâncias estabelecidas. Não por acaso, Maria perde os óculos durante sua participação nas manifestações, voltando a se encontrar numa situação de incertezas, dúvidas e sem foco.

Sentindo-se uma "penetra" em Maio de 1968 e ainda menos à vontade no Brasil com seu avô general, Maria olha com desconfiança para as construções históricas e sociais. Incomoda-se com a ingenuidade do internacionalismo da esquerda, mas sobretudo com a história tradicional encarnada por seu vizinho Luc: "[d]esconfia dessa história contada por ele, cronológica, livresca. Gosta mais das histórias à margem, prostituídas jogadas na sarjeta do tempo, que nunca serão contadas" (Hidalgo, 2016, loc. 477). A desconfiança da narrativa histórica torna-se anticolonialista quando o narrador evoca a experiência de ser estrangeira em Paris.

Ela sabe, por amigos morando em Paris desde a infância, que no colégio Anas viram Annes, Joãos viram Jeans, simples assim. Professores traduzem os nomes dos imigrantes para talvez torná-los mais familiares, menos ameaçadores. O próprio termo francês étranger, usado para o estrangeiro significa também estranho, aquele que destoa do meio. Quando ela entendeu isso, entendeu tudo. Todo estrangeiro é um intruso, ela sabe (Hidalgo, 2016, loc. 490).

Mas é certamente em Deslembro que a experiência dos exílios adquire maior carga dramática. A cena inicial do filme é ilustrativa nesse sentido. A heroína, embora pareça jovem demais para ser uma militante clandestina, debruçada na privada do banheiro, respiração ofegante, rasga seu passaporte, com, ao fundo, barulhos de máquinas (helicópteros, uma máquina de lavar?) que acrescentam ainda mais tensão à cena. A seguir uma voz feminina alegre a chama pelo apelido, carinhosamente, avisando que chegou em casa. Contrariamente ao que apontam diversos indícios, não se trata de uma fuga, mas simplesmente de uma adolescente que não quer deixar seus amigos, sua escola, seus livros para vol tar para um país que a ditadura e o esquecimento impediram que fosse seu.

- Je ne veux pas aller dans ton pays de merde!

- Não fala assim.

- Quoi? C'est pas là-bas qu'on tue et qu'on torture et maintenant c'est "Copacabana, mon amour" et tout ton petit tra-la-la nostalgique à la con, ça m'énerve! (Deslembro, 2018, 7m01s-7m09s).

Não é por acaso que a discussão é bilíngue, um diálogo de surdos: Joana negando a língua materna e a mãe ignorando a língua de adoção de Joana. Além do português e do francês, na casa de Joana, o companheiro da mãe, refugiado chileno, fala espanhol com seus dois filhos, incluindo na intriga uma dimensão latino-americana que não aprofundaremos aqui. Cada língua tem o seu momento tanto na França como no Brasil e nos momentos de tensão, elas se misturam, se chocam. Joana com sua revolta adolescente coloca os adultos diante das suas contradições, não apenas ideológicas, mas também ligadas à maternidade e à paternidade. Como Flávia Castro já fizera em Diário de uma busca, Deslembro assume a perspectiva dos filhos, mostrando o ressentimento desses por se sentirem preteridos à militância, vítimas dos caprichos revolucionários dos pais, mas também, como já vimos, dos silêncios, dos segredos e dos exílios. Para Joana, que de início recusa passeios, preferindo o apartamento onde recria seu universo parisiense com seus livros em francês, o verdadeiro exílio é voltar ao Brasil.

Como em A chave de casa e Rio-Paris-Rio, a volta de Joana e sua família para o Brasil também é condicionada pela Lei de Anistia. Se a narradora de Tatiana Salem Levy já apontava para uma memória do retorno restituída graças à narrativa dos pais, em Deslembro, a perspectiva de Joana, crítica e afetivamente distanciada do Brasil, oferece um contraponto à visão positiva e ingênua que a geração dos pais tem da anistia. "Olha o que se passa no Brasil, os milicos acabaram por ceder" (Deslembro, 2018, 8m01s), exclama com alegria Luis, companheiro da sua mãe. Nesse sentido, Joana não representa somente a memória impedida

\footnotetext{
${ }^{7}$ Tradução nossa: - Não quero ir para esse teu país de merda! / - Não fala assim. / - Por quê? Não é lá que se mata e se tortura? E agora é "Copacabana, mon amour" e toda essa babaquice nostálgica?! Isso me irrita!
} 
de um país que anistia e que sofre de amnésia. Joana é também o Brasil que sabe que deslembrou coisas importantes, que se esforça para lembrar, ousando para tanto fazer perguntas que incomodam os que preferem ou simplesmente precisam esquecer.

\section{Algumas considerações finais}

As narrativas brasileiras da geração dos filhos dos exilados das ditaduras latinoamericanas trazem uma nova perspectiva sobre a experiência do exílio e sobre a representação das ditaduras latino-americanas. Fatos históricos, traumas e vivências com pais mais ou menos radicais na sua militância política aparecem na geração pós-memorial diluídos em outras experiências, mas ainda assim onipresentes. Ao restituírem esses traços do passado na escrita, a geração dos filhos está consciente das armadilhas da memória infantil, das narrativas de segunda mão e da carga projetiva das imagens e dos objetos. Essas questões ganham mais importância do que os fatos em si, que já entraram para história - e que presidente algum poderá tirar. Daí a importância do componente metaficcional muito voltado para a memória e para o exílio, abordados, ao nosso ver, de uma maneira muito particular, tanto no que diz respeito aos temas quanto à forma. $O$ exílio ganha uma dimensão transgeracional, pois a experiência contamina certos narradores, autores e personagens que também vão se deslocar para escrever e/ou que vão se interessar sobre antepassados que também viveram essa experiência. $O$ exílio permite também que se contemple a própria história de outro ângulo, como em Rio-Paris-Rio. Esses cenários trazem também outras línguas e outras culturas e a presença delas nos romances ou em Deslembro chama atenção para a dimensão transnacional das memórias dos anos de chumbo. Enfim, a geração pós-memorial viveu também os fatos que seguiram as ditaduras e os exílios - derrocada dos grandes ideais, comissões da verdade, retorno de ideias autoritárias - e é também uma memória "presentificada" que oferecem a nós.

\section{Referências}

BADIOU, Alain (2018). On a raison de se révolter. Paris: Fayard.

BAYARD, Pierre (2013). De la mémoire à la postmémoire. Art Absolument, Paris, p. 5-9. Disponível em: https:/ / bit.ly/2wIpn3E. Acesso em: 11 set. 2019.

BONA, Camila de; RIBEIRO, Paulo Nunes (2018). Sobre a produtividade e a semântica do prefixo des- no português brasileiro atual. D.E.L.T.A., São Paulo, v. 34, n. 2, p. 611-634. Disponível em: http://www.scielo.br/pdf/delta/v34n2/1678-460X-delta-34-02-611.pdf. Acesso em: 12 out. 2012.

DESLEMBRO. Roteiro e direção de Flávia Castro. Paris: Films du Poisson. (96 minutos).

DREYFUS, Pauline (2017). Le déjeuner des barricades. Paris: Grasset.

FIGUEIREDO, Eurídice (2017). A literatura como arquivo da ditadura brasileira. Rio de Janeiro: 7 Letras.

FINAZZI-AGRÒ, Ettore (2014). (Des)memória e catástrofe: considerações sobre a literatura pós-golpe de 1964. Estudos de Literatura Brasileira Contemporânea, Brasília, n. 43, p. 179-190, jan./jun. Disponível em: https:// bit.ly/2tGvO5N. Acesso em: 12 out. 2019.

FUKS, Julián (2011). Procura do romance. Rio de Janeiro: Record.

FUKS, Julián (2015). A resistência. São Paulo: Companhia das Letras.

FUKS, Julián (2017a). A era da pós-ficção: notas sobre a insuficiência da fabulação no romance contemporâneo. In: DUNKER, Christian et al. Ética e pós-verdade. Porto Alegre: Dublinense. p. 73-93. [Kindle].

FUKS, Julián (2017b). Quero uma literatura ocupada pela política. [Entrevista concedida a] Ruan de Sousa Gabriel. Época. Rio de Janeiro, 28 jul. Disponível em: https://glo.bo/33z6tbP. Acesso em: 7 jul. 2019. 
GAGNEBIN, Jeanne Marie (2010). O preço de uma reconciliação extorquida. In: TELES, Edson; SAFATLE, Vladimir (Org.). O que resta da ditadura: a exceção brasileira. São Paulo: Boitempo.

GASPARINI, Philippe (2014). Est-il-je? Roman autobiographique et autofiction. Paris: Seuil.

GRELL, Isabelle (2014). L'autofiction. Paris: Armand Collin.

HIDALGO, Luciana (2013). Autoficção brasileira: influências francesas, indefinições teóricas. Alea, Rio de Janeiro, v. 15, n. 1, p. 218-231, jan./jun. Disponível em: http://www.scielo.br/pdf/alea/v15n1/a14v15n1.pdf. Acesso em: 11 set. 2019.

HIDALGO, Luciana (2016). Rio-Paris-Rio. Rio de Janeiro: Rocco Digital. [Kindle]

HIDALGO, Luciana (2017). Entrevista. [Entrevista concedida a] Yasmin Taketani. Suplemento Pernambuco, Recife, 3 abr. Disponível em: https:/ / bit.ly/2xJXCYQ. Acesso em: 8 de jul. 2019.

HIRSCH, Marianne (1997). Family frames: photography, narrative and postmemory. Cambridge; London: Harvard University Press.

HIRSCH, Marianne (2012). The generation of postmemory: writing and visual culture after the Holocaust. Cambridge; London: Harvard University Press.

HIRSCH, Marianne (2014). Connective histories in vulnerable times. PMLA, v. 129, n. 3, p. 330-348, maio. Disponível em: https://apps.mla.org/pdf/2014_pres_address_pmla.pdf. Acesso em: 6 out. 2019.

LEVY, Tatiana Salem (2007). A chave de casa. Rio de Janeiro: Record.

LEVY, Tatiana Salem (2011). Dois rios. Rio de Janeiro: Record.

LEVY, Tatiana Salem (2014). Paraíso. Rio de Janeiro: Foz.

MARCHETTO, Arthur (2018). Reflexões sobre a autoficção, a pós-ficção e o "eu" na literatura. Escotilha, 27 set. Disponível em: https:// bit.ly/38YSPQ2. Acesso em: 6 out. 2019.

ONFRAY, Michel (2018). L'autre pensée 68. Paris: Grasset.

PESSOA, Fernando (1973). Deslembro incertamente. In: PESSOA, Fernando. Novas poesias inéditas. Lisboa: Ática. p. 116. Disponível em: http://arquivopessoa.net/textos/2377. Acesso em: 13 out. 2019.

RICEEUR, Paul (2000). La mémoire, l'histoire, l'oubli. Paris: Seuil.

SELIGMANN-Silva, Márcio (2014). Imagens precárias: inscrições tênues de violência ditatorial no Brasil. Estudos de Literatura Brasileira Contemporânea, Brasília, n. 43, p. 13-34, jan./jun. Disponível em: https:// bit.ly/3a8mBmI. Acesso em: 12 out. 2019.

SULEIMAN, Susan Rubin (2002). The 1.5 generation: thinking about child survivors and the Holocaust. American Imago, Baltimore, Maryland, v. 59, p. 277-295. Disponível em: https://bit.ly/2RgKsK2. Acesso em: 22 jan. 2020.

SZURMUK, Mónica; IRWIN, Robert McKee (Coord.) (2009). Diccionario de estudios culturales latinoamericanos. Ciudad del México: Siglo XXI Editores.

VIDAL, Paloma (2003). Literatura e ditadura: alguns recortes. Escrita de Letras, v. 5, s.p. Disponível em: https:/ / www.maxwell.vrac.puc-rio.br/3551/3551.PDF. Acesso em: 12 out. 2019.

VIDAL, Paloma (2009). Algum lugar. Rio de Janeiro: 7Letras.

VIDAL, Paloma (2012). Mar azul. Rio de Janeiro: Rocco Digital [Kindle].

VIDAL, Paloma (2015). Literatura e reparação: um percurso. Lua nova, São Paulo, n. 96, p. 55-70. Disponível em: https:/ / bit.ly/3d81B1p. Acesso em: 12 out. 2019.

VIDAL, Paloma (2017). Ensaio de voo. São Paulo: Quelônio. 